https://doi.org/10.18485/analiff.2020.32.2.14

811.163.41'272 (497.6)"1945/1990"

Александра Р. Савић*

Удружење лектора Републике Српске

Originalni naučni rad

Бања Лука

Primljen: 19.07.2020

Prihvaćen: 22.10 .2020

\title{
ИНТЕРДИСЦИПЛИНАРНИ ОДНОС ЈЕЗИКА И ПОЛИТИКЕ
}

\section{(ИСПРЕКИДАНИ ЕКВИЛИБРИЈУМ И ЈЕЗИЧКА ПОЛИТИКА У БОСНИ И ХЕРЦЕГОВИНИ ОД 1945. ДО 1990)}

\begin{abstract}
У раду се представља интердисциплинарни однос између језика и политике. Основно полазиште овог рада јесте да су и политика и језик комплексни и вишедимензионални друштвени феномени који се не могу посматрати независно - и један од другога али и од читавог низа других друштвених феномена. Друга хипотеза рада гласи да још увијек има прилике за снажнију интеракцију ових поља у научном смислу. Студијом случаја приказујемо како путем једне политиколошке теорије (испрекиданог еквилибријума) можемо анализирати језичке процесе и то у овом случају језичку политику у Босни и Херцеговини од 1945. до 1990. Анализа је показала да, насупрот поставкама ове теорије, период равнотеже у јавним политикама које смо испитали не одликује стабилност него низ мањих, радикалних промјена. Оно што смо примијетили у овој огледној скици јесте да и једна и друга дисциплина имају велику корист од интердисциплинарног приступа. На основу резултата, закључујемо да би било корисно у теорију испрекиданог еквилибријума укључити истраживања јавних и језичких политика у подијељеним друштвима, односно вишенационалним заједницама. Лингвистика, заправо језичка политика и планирање, могу уврстити ову теорију у свој методолошки апарат како би се анализирали дужи периоди у историји језичке политике, нарочито у земљама у којима се политичко-правна уређења драстично смјењују, и тиме извукли закључци важни за будуће политике.
\end{abstract}

Кључне ријечи: језик, политика, интердисциплинарност, теорија испрекиданог еквилибријума, политичка лингвистика, језичка политика

*_aleksandra.suvira@yahoo.com 


\section{1. Језик и политика}

С обзиром на то да је језик друштвени феномен (Filipović, 2018: 14), а да је човјек по природи политичко и друштвено биће (Aristotel, 1988: 26), појмови и феномени политике и лингвистике нужно се преплићу. За научнике, нарочито западне политичке мислиоце (Chilton, 2004: 19), двије области блиско су повезане на фундаменталном нивоу (Chilton, 2004: 19). Ферклоф (Fairclough, 1989: 23)чак примјећује да многи уџбеници и теоретичари пишу о вези између ових дисциплина као да се ради о два независна идентитета која случајно долазе у контакт. Насупрот томе, он тврди да је ријеч о суштинском и дијалектичком односу јер „linguistic phenomena are social phenomena of a special sort, and social phenomena are in part lingustic phenomena" (Fairclough, 1989: 23).

Бројни примјери иду у прилог тврдњама овог аутора. Рецимо, сасвим је сигурнода је избор једног наспрам другог нарјечја у именовању стандардног језика и политичко питање. Такође, одабир језика у образовању - који ће то језици бити и у којем обиму - праве не само језички стручњаци него и државна политика и стратегија. Напослијетку, у односу између самих лингвиста, политика се такође намеће као важан чинилац. Већи утицај на језик и на језичку политику свакако имају они језикословци који се налазе у националним језичким институцијама него они који тамо нису, па и онда када придоносе рјешавању кључних језичких питања. Можемо чак говорити и о томе даје сваки дискурс потенцијално политички (Wilson, 2001: 398), поготово у свјетлу критичке анализе дискурса (Wodak, 2009; Fairclough, 1989; Van Dijk, 1998). Бројни истраживачи сматрају да се у случају спајања језика и политике ради о изузетно атрактивномприступу (Okulska \&Cap, 2010: 3) који привлачи све више аутора, односно да је интердисциплинарни однос између лингвистике и политикологије права „сњежна кугла“ (Okulska \&Cap, 2010: 7) која, у потрази за одговорима, скупља успут сазнања и резултате многих других области истраживања. Све то јасно назначава да је ријеч о актуелној и утицајној теми која је, занимљиво, своју савременост и свевременост успјела да задржи током цијеле историје проучавања друштва. 
ИНТЕРДИСЦИПЛИНАРНИ ОДНОС ЈЕЗИКА И ПОЛИТИКЕ

\section{2. Методски оквир и хипотезе}

Основнополазиште овог рада јесте да су и политика и језик комплексни и вишедимензионални друштвени феномени који се не могу посматрати независно - и један од другога али и од читавог низа других друштвених феномена.Друга хипотеза рада гласи да још увијек има прилике за снажнију интеракцију ових поља у научном смислу. Иако и једна и друга област теже интердисциплинарности, постоји још неколико могућих додирних тачака ове двије науке, што у теоријском, што у методском смислу. Овом питању прилазимо искључиво из угла интердисциплинарности која нам омогућава да се несметано крећемо дуж сазнања и резултата једне и друге науке и посматрамо шта им је заједничко, по чему се разликују и рјешавању којих проблема могу допринијети ако сарађују. Постулат од којег полазимо јесте теорија комплексности по којој не постоје атомизовани и изоловани елементи у друштву, који би се линеарно и једноставно посматрали, већ се комплексна истраживања фокусирају на „процесе и догађаје у интеракцији у оквиру мрежа или система“ (Filipović, 2018: 122). Методолошки апарат који потенцира нелинеарно, отворено и вишедимензионално истраживање обезбиједиће нам довољан оквир за почетно посматрање ових друштвених појава и „улазак“ у њихов комплексан однос. За изучавање саме релације два назначена појма, користиће нам историјска метода, помоћу које пратиморазвој два феномена још од почетака размишљања о човјеку као друштвеном бићу. Дискурсно-историјски приступ Рут Водак (Ruth Wodak,2015) послужиће нам да разне покушаје повезивања ове двије дисциплине у прошлости ставимо у одговарајући историјски и политички контекст и разумијемо друштвене околности које су произвеле одређене интердисциплинарне покушаје. Искористићемо, у студији случаја, и једну познату политиколошку методу из анализе јавних политика - теорију испрекидане равнотеже.

\section{3. Од ,zoon politicon“-а до ,језичког обрта у науци“}

Још је Аристотел говорио о човјеку као „zoon politicon“-у, бићу које карактерише употреба језика (Aristotel, 1988). Реторика је у антици имала статус посебне дисциплине и нарочито се на политичким трговима и форумима цијенила моћ убјеђивања. Модерна мисао о повезаности ова два појма јављасе након чланка Џорџа Орвела из 
1946. (Joseph, 2004: 351) ${ }^{1}$. Са друге стране, развојем масовне комуникације, јавио се интерес за језик и ефекте његове употребе (Wodak\& Forchter, 2018: 2), поготово у политичке сврхе.Након Другог свјетског рата, паралелно се развијају квантитативна истраживања која се тичу комуникације и мас-медија и квалитативна истраживања Франкфуртске школе (Wodak\& Forchter, 2018: 2). Сосиров структурализам, као камен-темељац модерне лингвистике (Filipović, 2015), већ је по некима могао бити зачетник интердисциплинарног и трансдисциплинарног приступа (Filipović, 2018; Filipović, 2015)² у науци. Надаље се на овај концептнадовезују критике марксиста да језик није неутралан (Okulska\&Cap, 2010: 4)и да продукција и репродукција значења имају политичке посљедице (Joseph, 2004: 348).

Међутим, и даље су у двадесетом вијеку политика и језик прилично раздвојена поља; вежу их понека сродна истраживања, а још неколико година ће проћи док се не удруже сазнања и резултати разних дисциплина, који ће створити плодно тло за међудисциплинарна истраживања у правом смислу. У лингвистици се смјењују генеративна граматика, која језик посматра као систем и не узима у обзир друштво и ефекте које околина има на језик и обрнуто, и са друге стране, читав низ теоретичара који уводе друштвену компоненту у анализу језика (етнолингвистика, социолингвистика). Са друге стране, захваљујући феминистичкој критици, брише се граница између приватног и јавног (Wodak\&Forchter, 2018: 3) и тиме се теорија ослобађа хируршких резова у испитивању друштва, јер постаје јасно да су ови феномени флуидни, комплексни и свепрожимајући. Друштвене науке, међу којима су и политичке, такође доживљавају својеврсни преврат, који ће многи назвати „лингвистичким обртом“ у друштвеним наукама (Corcoran, 1989).

1 Орвелов напис „Politics and English Language“ говори о особинама модерног енглеског језика који је исувише апстрактан, препун фраза, претенциозне лексике и ријечи које не значе ништа, што се нарочито односи на политичке текстове и наступе (Orwell, 1968).

2 Јелена Филиповић, цитирајући одломак из Опште тингвистике, примјећује да овај аутор, иако покушава поставити лингвистику на исту раван са природним наукама, ипак у једном тренутку ставља акценат на друштвени аспект језичке употребе (Filipović, 2018: 12) - „Još je očiglednija veza lingvistike sa kulturom uopšte: u životima pojedinaca i društava govor je značajniji od svega drugog. Nezamislivo je da lingvistika nastavi da bude oblast istraživanja dostupna samo malom broju stručnjaka“. 
On one hand, humanists (...) including some of the most celebrated philologist and historical linguists, insist that languge, as a capacity for expressing the most intimate, emotional, and moral concerns of humankind and capable of such manifest cultural diversity and change, cannot possibly be isolated from the nexus of personal experience or concretized as an autonomous, universal structure. On the other hand, various streams of the Marxist tradition (...), The Frankfurt School, French poststructuralism, and contemporary feminism (...) insist that somethig so intrinsic to human consciousness and fundamental to social life could never be autonoumous (...) and external to the constitution of society (Corcoran, 1989: 60).

Овај одјељак осликава читав преокрет у науци, који је настао захваљујући напорима и закључцима многих дисциплина. У складу са новом перспективом, политичке науке се окрећу према приступу који се фокусира на политичку моћи језик (Corcoran, 1989: 67). Исто је и са лингвистиком, у којој се од деведесетих наовамо говори о истраживањима политичког дискурса.

Политичка лингвистика (Политолингвистика) била је први покушај да се створи научна дисциплина за истраживање политичког дискурса (Wodak, 2009: 580). Бавила се прагматиком, текстуалном лингвистиком и истраживањима медија (Wodak, 2009: 580), као и језичком политиком у тоталитарним режимима. Насљедница ове дисциплине је анализа политичког дискурса (Okulska \&Cap, 2010). Ради се о перспективи коју одликује хетерогеност и фрагментарност, као и терминолошки либерализам (Okulska \&Cap, 2010: 3). Управо захваљујући томе, она дјелује као слојевита, непрецизно дефинисана област којом се баве истраживачи разних усмјерења, и баш зато не постоји јасан теоријски оквир нити методолошка упутства, него се тај апарат преузима и из политичких наука, из лингвистике, али и других дисциплина, попут историје, филозофије, социолингвистике, антропологије, итд., те је затодоминантна особина свих радова и истраживања чињеница да они не редефинишу основне концепте политичког дискурса него проналазе додатне алате за постојеће анализе, као што је случај са критичком лингвистиком (Okulska \&Cap, 2010: 4). 


\section{4. Предмет проучавања, класификација и основни појмови двију дисциплина}

Већ смо у претходном одјељку истакли како не постоји јединствена методологија или теоријска поставка која прати истраживања језика и политике (Okulska \& Cap, 2010: 4), као што нема јединствене парадигме која окупља сродне приступе, али ћемо ипак у овом раду покушати скицирати основне смјернице у оквиру којих истраживачпочетник може да се креће. Најприје полазимо од саме политике и проблема њеног дефинисања јер се ради о суштински спорном појму (Кецмановић, 2010) који једни „везују за ауторитарну расподјелу средстава за живот, други за државу и власт, трећи за политичке сукобе и борбе, а четврти, напротив, за превенцију и мирно рјешавање унутрашњих и међународних конфликата уз помоћ дијалога, концесија, компромиса и консензуса“" (Кецмановић, 2010: 16). Могуће је направити одређену разлику у оквиру предмета проучавања политике, с обзиром на то да се овај појам традиционално дијели на три велике области које у ствари представљају разлику између „форме, процеса и садржаја““ (Матић, 1993: 872-884)3․

polity означава политички поредак и систем неке заједнице, односно институционални и нормативни оквир државе,

politics представља сам политички процес у који убрајамо актере, процедуре, јавно дјеловање, али и традиционалне политичке концепте као што су моћ, консензус, итд.;

policy, као трећи чинилац ове везе, јесте политика као конкретна активност одлучивања, спровођења јавних активности и рјешавање проблема (Матић, 1993: 872).

Уколико овим дефиницијама придружимо лингвистичке теоријске спознаје, примјећујемо да су аутори направили идентичну подјелу у проучавању односа између језика и политике. Дакле, у проучавању језика и друштва, тачније политике, разликујемо:

language of politics, originally understood (...) as "the $[. .$. rhetoric of political activities and of politicians acting in their political capacity," and the

3 Ову разлику одлично илуструју појмови у енглеском језику, које ћемо и ми користити. У српском језику не постоје адекватни називи за ове три области, те се све преводе са „политика“. 
politics of language - understood as "policies and decisions about official and standard languages, language planning, language academies, and educational language policies" (Okulska\&Cap: 2010: 7).

Још прецизније, у оквиру интердисциплинарне области која се бави питањима утицаја језика на политику и обрнуто, развиле су се двије потпуно независне и заокружене области које још боље илуструју горенаведену подјелу политике. Ријеч је о анализи политичког дискурсакоја проучава „language as a form of social practice“ (Fairclough, 1989: 20), што у потпуности одговара дефиницији политике као процеса, те о језичкој политици и планирању, интердисциплинарној области коју обично дефинишу као активност државе у области језика (Filipović, 2018: 87), што опет одговара појму policy.

Ради се о двије прилично комплексне и разгранате дисциплине, па ова класификација може да послужи као потенцијални методолошки оквир за будуће анализе. Но, треба имати у виду да „роlitics is very largerly the use of language, even if the converse is not true, not every use of language is political“" (Chilton, 2004: 14), што значи да, иако је ријеч о изузетно примамљивим и актуелним пољима у савременој науци, ипак не треба губити из вида да анализа оваквог типа лако може прећи у политичку, на шта упозоравају и многи лингвисти сматрајући да „discourse analyst too are political animals“ (Chilton, 2004:205).

У наредном дијелу рада, направићемо синтезу досад реченог и на примјеру показати како путем једне политиколошке методе можемо анализирати језичку политику. Студија случаја коју смо одабрали корисна је и због тога што се у њеној анализи, мада у овом случају не директно, преламају за обје науке веома важни појмови идеологије и моћи.

\section{5. Студија случаја - испитивање језичке политике у БиХ од 1945. до 1990.}

Важност сједињавања политиколошких и лингвистичких теорија и метода ради што бољег и потпунијег интердисциплинарног истраживања илустроваћемо анализом језичке политике у Босни и Херцеговини између 1945. и 1990, и то путем познате политиколошке теорије испрекиданеравнотеже.Појам је у анализу јавних политика 
пренесен из биологије и објашњава еволуцију,заступајући мишљење да се еволутивне промјене догађају у наглим прекидима (Poljak, 2016: 3),што стоји насупрот теорији да се развој иадаптацијеу природи дешавају постепено.У анализи јавних политика, дефинишемо је

kao proces stvaranja neke politike na osnovu kojeg se određena politika brzo institucionalizira te nakon toga ulazi u fazu stabilnosti. Zbog različitih utjecaja stabilnost nakon dugog vremena počinje pucati, potom se uspostavlja potpuna nova institucionalna arhitektura, te stvaranje neke javne politike ponovno ulazi u stabilnost. $\mathrm{Na}$ taj način teorija prikazuje dinamiku u kojoj se javne politike kontinuirano nalaze (Jones \& Baumgartner, 2012: 4, према Poljak, 2016: 3). ${ }^{4}$

Творци теорије испрекиданог еквилибријума виде историју јавних политика као непрестано смјењивање између равнотеже и дестабилизације (Jones\& Baumgartner, 2012: 3), при чему се динамика ових промјена одвија тако да дестабилизација долази нагло и подразумијева радикалне промјене у кратком времену, а период равнотеже траје дуго и не одликују га неочекиване трансформације него поступна мијењања политике. Језичком политиком и планирањем у овом раду сматрамо „организовану, циљану и дугорочну активност институција државе на различитим аспектима статуса, форме и домена употребе одређеног језичког варијетета“" (Filipović, 2018: 87).

Језичка политика коју проучавамо 1945. године ушла је у ново раздобље које је потрајало све до 1990 (Шипка, 1999). Босна иХерцеговина је била република у саставу Југославије ${ }^{5}$, и њена језичка политика је у једну руку пратила савезну, али се дијелом и ослањала на сопствену, аутономну активност на овом пољу. У оквиру наведеногпериода, испитаћемо 1) када долази до промјена језичке политике, тј. шта карактерише период испрекиданостии 2) како изгледа период равнотеже.

4 С обзиром на то да се ради о обимној и богатој теорији која до данас није систематизована (Poljak, 2012: 2), у овом раду држаћемо се почетних појмова и дефиниција. За потребе анализе, као и због ограниченог простора, служићемо се само концептима прекида и равнотеже.

5 Заједничким називом Југославија избјегавамо дуге и за потребе овог написа конфузне скраћенице којима се илуструје уставна промјена назива савезне државе, а подразумијевамо и ДФ Југославију, ФНР Југославију, као и СФР Југославију. 
До испрекиданости у језичким политикама у Босни и Херцеговини дошло јенакон наглих и неочекиваних нестабилности у друштву, у овом случају након Другог свјетског рата, што се поклапа са првим дијелом теорије испрекидане равнотеже. Такође, након 1990. године, када овафаза језичке политике и завршава, она се наново радикално мијења, и то, нажалост, након још једног рата. Међутим, не само да се у овим прекидима мијења језичка политика, преокрећу се из коријена и: политички систем, назив језика, поглед на језик, актери језичких политика, али и тип језичке политике. У СР Босни и Херцеговни, главни актери јавних политика су политичке елите и лингвисти (Савић, 2020), и ради се о политици одозго према доље.

Кад је посриједи одговор на друго питање,било би логично да, у складу са овим моделом анализе јавних политика, доба еквилибријума траје скоро педесет година и да у том времену језичка политика доживљава одређена побољшања или измјене, али да се ништа радикално не преображава. Како бисмо то провјерили, фокусираћемо се на документе и дешавањана пољу језика у овој републициза вријеме друге Југославије (в. и Савић, 2020; Шипка, 1999 за детаљан опис језичке политике у Босни и Херцеговини од 1945. до 1990).Језичку политику пратио је велики број докумената: најприје је Босна и Херцеговина билаукљученау рад на стандардизацији српскохрватског, али од 1965, након сукоба српских и хрватских лингвиста (Шипка, 1999), започиње сопствену политику на основу које поступају и све политичке, језичке и стручне институције и појединци $\left(\right.$ Савић, 2020) ${ }^{6}$. У периоду самосталне политике, Шипка (1999: 12-16) издваја три фазе језичке политике. Прва је фаза реаговања у којој актери језичке политике одговарају на Декларацију о називу и положају хрватског књижевног језика као и на ставове изнесене уПредлогу за размишљање, осврћући се на сложену босанскохерцеговачку националну структуру и на посљедице које би опредјељивање за један стандард могло

6 Разлог који је довео до самосталног иступања у креирању и спровођењу језичке политике у БиХ био је сложена структура Босне и Херцеговине због које није било могуће спровести радикалне резове. „Самостална језичка политика Босне и Херцеговине трајала је од 1967. (1970) до распада СФРЈ, а била је одговор на разлаз међу српским и хрватским лингвистима око назива и положаја заједничког језика. Подразумијевала је двочлани назив језика, употребу оба писма и поштовање принципа језичке толеранције и индивидуалне језичке слободе“ (Савић, 2020: 2). 
донијети ${ }^{7}$ народима и народностима ове федералне јединице. У другој, фази темељних докумената ${ }^{8}$, можемо говорити о самосталној политици коју одликује именовање босанскохерцеговачког језичког израза, прокламовање индивидуалног права на избор изражајних средстава односно варијаната језика, те равноправност писма. Трећу фазу карактеришу акциони документи ${ }^{9}$ који се углавном односе на провођење досадашњих закључака и политика у пракси. Име језика укупно је мијењано три пута (Шипка, 1999: 16) - српски или хрватски 1946; српскохрватски 1963; српскохрватски односно хрватскосрпски језик ијекавског изговора 1974.

По нашем мишљењу, овај дуги низ година не може се назвати периодом баланса и стабилности, с обзиром на то да је било неколико промјена назива језика, закључака о варијантама језика, као и важних докумената језичке политике. Прије бисмо, на основу изнесеног, могли закључити да наведени период такође карактеришу изненаднеи прилично драстичне промјене. Разлог тих промјена свакако је неслагање главних актера језичке политике, због чега у ову анализу обавезно треба укључити и: анализу политичког система и односа у заједницама које одликује постојање више центара моћи у одлучивању, али и суживот више нација односно народа. Закључујемо, на основу нашег прегледа, да нагли прекиди јавних политика у овом случају настају искључиво промјенамаполитичког система које су праћене сукобом и потпуним нестанком и преображавањем дотадашњег система, а да се поремећаји у периоду еквилибријума догађају због унутрашњих сукоба у које убрајамо националне нетрпељивости и постојање више актера јавне политике који су подједнако моћни.

Оно што можемо примијетити у овој огледној скици јесте да и једна и друга дисциплина имају велику корист од интердисципли-

7 Изјава Извриног комитета ЦК СКБИХ 1967; Отворено писмо наставника и сарадника Филозофског факултета у Сарајеву 1967; Оијене и ставови Извриног комитета ЦК СКБИХ 1968. За потпуни преглед ових докумената, као и језичке политике БиХ, видјети Шипка 1999.

8 Зактучйи Симпозијума о језичкој толераниији 1970; Книжевни језик и книжевнојезичка политика у Босни и Херцеговиини 1971; Закъучци Просвјетнокултурног вијећа Скупштине СР БИХ 1971.

9 Закључии Мостарског савјетоваға о провођену кюижевнојезичке политике 1974; Зактучии и предлози истраживачке групе Института за језик и књижевност... 1975. 
нарног приступа. Анализа показује да би било корисно у теорију испрекиданог еквилибријума укључити истраживања јавних и језичких политика у подијељеним друштвима, односно вишенационалним заједницама. Лингвистика, заправо језичка политика и планирање, могу уврстити ову теорију у свој методолошки апарат како би се анализирали дужи периоди у историји језичке политике, нарочито у земљама у којима се политичко-правна уређења драстично смјењују,и тиме извукли закључци важни за будуће политике. Поред тога, било би веома корисно проширитианализу на цјелокупну историју језичке политике у Босни и Херцеговини, али и упоредити резултате са другим земљама са сличним језичким, политичким и друштвеним устројством.

\section{6. Закључак}

Политика и лингвистика су два веома испреплетена и међузависна феномена. Захваљујући развоју друштвених наука, као и интердисциплинарним покушајима са обје стране у посљедњих педесет година, данас имамо велики избор теорија, метода и доминантних тема које можемо користити у истраживањима. Један од основних разлога писања овог рада био је да, помоћу анализе досадашњих напора и лингвиста и политиколога (додуше, њих мање), одговоримо на питање да ли још увијек постоје неки неријешени проблеми у оквиру ових области, а који би могли бити боље образложени да су теоретичари посегли за сазнањима сродних области, у које укључујемо и ове двије. На основу студије случаја у којој смо користили политиколошку теорију испрекиданог еквилибријума, показали смо најприје како је могуће уклапати различите методе и теоријске приступе у оквиру двије сродне дисциплине, а са друге стране, што је за развој друштвених наука још важније, та анализа је показала да су ова истраживања корисна и да резултати произашли из њих могу бити примијењени у пракси. Нажалост, још увијек доминантно монодисциплинарна пракса наших образовних система и научних опредјељења ријетко показује да има простора да и једна и друга дисциплина присвоје позитивна сазнања и методе из оне друге. Политика као друштвена активност (без одређења њеног испољавања као лошег или доброг) и језик као друштвени феномен не могу да се изучавају у оквирима уских модела, јер живот и наука нису једнодимензионални и линеарни него сло- 
жени системи у којима ниједан елемент не постоји независно од неког другог - „све што на нашем свету постоји састављено [је] од мноштва комплексних (нелинеарних) система чије компоненте се не могу анализирати појединачно кроз истраживање једноставних двосмерних веза“"(Filipović, 2018: 122).

Што се тиче даљег развоја интердисциплинарне области коју смо истраживали, за крај ћемо поменути двије теме за даље промишљање овог односа. Једна је Чилтонова(Chilton,2004: 198)опсервација да политика не подразумијева само конфликт него и сарадњу, што отвара сасвим ново поље непресушних тема за ауторе. Друга долази из пера Рут Водак(Wodak\&Forchter, 2018: 5), која је такође једна од водећих ауторки која у језичка испитивања уводи политички контекст. Она, наиме, издваја три приступа у изучавању комуникације: оне оријентисане на извор, оне који се тичу поруке и оне који се фокусирају на примаоце. Ставови примаоца су ријетко тема оваквих анализа, стога сматрамо да би изучавање њихових ставова, нарочито у виду квантитативних и квалитативних анализа, значајно допринијело проучавању језика и друштва односно политике.

\section{ЛИТЕРАТУРА}

Aristotel 1988. Politika, Tomislav Ladan, Zagreb: Globus.

Chilton, P. 2004. Analysing Political Discourse: Theory and Practice. London, New York: Routlege.

Corcoran, P. 1989. Language and Politics, Swanson, D. L., Nimmo, D.,New directions in Political Communication, 51-86, Newbury Park, California: SAGEPublications.

Fairclough, N. 1989. Language and Power. New York: Longman Inc.

Filipović, J. 2015. Transdisciplinary Approach to Language Study, London: Palgrave Macmillan.

Filipović, J. 2018. Moć jezika: ogledi iz kritičke sociolingvistike, Beograd: Zadužbina Andrejević.

Jones, B. D. \& Baumgartner, F. R. 2012.From There to Here: Punctuated Equilibrium to the General Punctuation Thesis to a Theory of Government Information Processing, The Policy Studies Journal, 40/1, 1-19.

Joseph, J. E. 2004. Language and politics, Davies, A., Elder, C., The Handbook od Applied Linguistics, 347-367, Oxford: Blackwell Publishing Ltd. 
Кецмановић, Н. 2010. Политика, држава, моћ, Београд: Чигоја.

Матић, М. 1993. Енциклопедија политичке културе, Београд: Савремена администрација.

Okulska, U. \& Cap, P. 2010. Perspectives in Politics and Discourse, Amsterdam: John Benjamins Publishing.

Orwell, G. 1968. Politics and the English Language, The collected essays, journalism and letters of George Orwell, 4/1, 127-140, New York: Harcourt, Brace, Javanovich.

Poljak, Ž. 2016.Operacionalizacijateorijeisprekidaneravnoteže, Političkamisao, $53 / 3,139-162$.

Савић, А. 2020.Интерпретације босанскохерцеговачког језичког израза и језичке политике која га је пратила, Србистика данас, у штампи.

Шипка, М. 1999. Стандардни језик у Босни и Херцеговини у документима језичке политике, Budapest: Open Society Institute.

Van Dijk, T. A. 1998. What is Political Discourse Analysis?Belgian Journal of Linguistics, 11/1, 11-52.

Wilson, J. 2001. Political discourse, Schiffrin, D., Tannen, D., Hamilton, H., The Handbook of Discourse Analysis, 398-415, Oxford: Blackwell Publishing.

Wodak, R. \&Forchter, B. 2018.Introducing the language-politics nexus, Wodak, R. \&Forchter, The Routledge Handbook of Language and Politics, 1-15, London and New York: Routledge.

Wodak, R. \& Reisigl, M. 2015. The discourse-historical approach (DHA). In R. Wodak, \& M. Meyer (Eds.), Methods of critical discourse studies (3rd ed.),23-61, London: Sage.

Wodak, R. 2009. Language and Politics, Culpeper J., Katamba, F., Kerswill, P., Wodak, R., McEnery, T.,English Language, 576-593, Basingstoke: Palgrave. 


\title{
Aleksandra Savić
}

\section{INTERDISCIPLINARY RELATIONSHIP BETWEEN LANGUAGE AND POLITICS}

\begin{abstract}
Summary
This paper examines the relationship between language and politics. We defined both language and politics as social phenomena which are connected at the fundamental level (Fairclough, 1989). The basic hypothesis of this research is that language and politics are complex and multidimensional social phenomena which cannot be divided and studied independently. In this paper we applied several scientific paradigms: interdisciplinary approach in the social sciences, complex theory, historical method, and the historical-discursive approach that is developed by Ruth Wodak (2015). In the case study chapter, we used the punctuated equilibrium theory from public policy analysis. Political linguistics or Politolingusitics was the first attempt to create an academic discipline for political analysis of language and the other way around (Wodak, 2009), and the successor of this paradigm is political discourse analysis. Even if there is no standard methodology or one leading theory of this connection between language and politics, we can sketch some of the most important subjects of research in both disciplines. Political sciences are divided into polity, politics, and policy studies, and we found the exact approach in linguistics, because there is the language of politics and there is the politics of language.
\end{abstract} theory

Key words: language, politics, interdisciplinarity, punctuated equilibrium 